\title{
Hf-Based High- $\kappa$ Dielectrics: A Review
}

\author{
S. KOL AND A.Y. ORAL* \\ Department of Materials Science and Engineering, Gebze Technical University, Gebze, Kocaeli 41400, Turkey
}

(Received January 10, 2019; revised version October 1, 2019; in final form October 23, 2019)

In the last decades, the number of transistors per chip with integrated circuits has increased leading to reduction in the thickness of silicon dioxide used as gate dielectrics. However, at small dielectric thicknesses leakage current formation has begun due to the quantum tunneling effect. Thus, it became essential to replace $\mathrm{SiO}_{2}$ with alternative dielectrics with high dielectric constant to maintain the same capacitance at higher gate dielectric thicknesses. This review analyzes alternative high- $\kappa$ dielectric materials substituting for $\mathrm{SiO}_{2}$. For this reason, the properties of materials with high dielectric constant are compared to $\mathrm{SiO}_{2}$ with a special emphasis on $\mathrm{HfO}_{2}$, since it is the most promising high- $\kappa$ dielectric to replace $\mathrm{SiO}_{2}$. The fundamental points concerning $\mathrm{HfO}_{2}$ gate dielectrics are their high dielectric constant and their thermodynamic stability when in contact with Si. In this article, properties of $\mathrm{HfO}_{2}$ fabricated with different coating methods and doped with different elements such as $\mathrm{N}, \mathrm{Si}, \mathrm{Al}$, Ti and Ta have been compared and discussed. In the conclusion part, we have summarized the results of characterization obtained by X-ray diffraction, scanning electron microscopy, leakage current density-voltage $(J-V)$, capacitance-voltage $(C-V)$ and $\mathrm{UV}$-vis spectroscopy of $\mathrm{HfO}_{2}$ thin films.

DOI: 10.12693/APhysPolA.136.873

PACS/topics: $\mathrm{HfO}_{2}$, gate dielectrics, FinFET, thin films

\section{Introduction}

Silicon oxide has been utilized as gate dielectric material for over 40 years [1]. However, progressive minimization of transistor dimensions requires the gate oxide layers with very low thickness leading to unwanted leakage currents due to the tunneling effect. To solve this problem, alternative gate dielectric materials have been investigated with higher dielectric constant (high- $\kappa$ ) than that of $\mathrm{SiO}_{2}$. These high- $\kappa$ candidates are $\mathrm{Ta}_{2} \mathrm{O}_{5}, \mathrm{TiO}_{2}, \mathrm{ZrO}_{2}$, $\mathrm{Al}_{2} \mathrm{O}_{3}, \mathrm{HfO}_{2}, \mathrm{HfO}_{x} \mathrm{~N}_{y}, \mathrm{HfSi}_{x} \mathrm{O}_{y}, \mathrm{HfAl}_{x} \mathrm{O}_{y}$, or nitrided $\mathrm{SiO}_{2}$ and $\mathrm{Zr}$-based oxides. These candidates should have high dielectric constant and be thermally stable when in contact with $\mathrm{Si}$. Oxides of metals from group $2 \mathrm{~A}$ like $\mathrm{CaO}$ and the high- $\kappa$ oxides such as $\mathrm{TiO}_{2}, \mathrm{Ta}_{2} \mathrm{O}_{5}$ and $\mathrm{Nb}_{2} \mathrm{O}_{5}$ have not been preferred in the electronic circuits because of their reactivity with $\mathrm{Si}$. Therefore, dielectrics alternative to $\mathrm{SiO}_{2}$ are restricted to the high- $\kappa$ oxides such as $\mathrm{HfO}_{2}, \mathrm{ZrO}_{2}, \mathrm{Al}_{2} \mathrm{O}_{3}, \mathrm{Y}_{2} \mathrm{O}_{3}$, and $\mathrm{La}_{2} \mathrm{O}_{3}$. Among these candidates, $\mathrm{HfO}_{2}$ gate dielectric layers are the most suitable materials because of their thermal, electrical, and mechanical properties [2-8].

High- $\kappa$ gate oxides emerged into the market with Intel's new generation $45 \mathrm{~nm}$ microprocessors in 2007 . Next, Intel produced high $-k /$ metal gates with $32 \mathrm{~nm}$ width in 2009. In both transistors, silicon oxide-based insulator has been replaced by hafnium-based oxides. Furthermore, polycrystalline silicon gates were substituted with metal-gates [9, 10]. In 2011, $22 \mathrm{~nm}$ chips, using high- $k$ gate dielectrics, were demonstrated based on $3 \mathrm{D}$ tri-gate transistor architecture by Intel. Then, Intel started mass production of $14 \mathrm{~nm}$ microprocessors

*corresponding author; e-mail: aoral@gtu.edu.tr formed by 3D transistors in 2014 using the same gate oxide layer [11-13]. Afterwards, Samsung announced $10 \mathrm{~nm}$ FinFET (fin field effect transistor) technology on February 23, 2017. FinFET is a 3D double-gate transistor set up, where the gate is positioned on multiple sides of the channel or wrapped around the channel, forming a double gate structure. By means of this structure, transistors with smaller gate lengths can be produced with increased efficiency and performance. For instance, $10 \mathrm{~nm}$ FinFETs bring up 27 percent higher performance and 40 percent less power consumption than $14 \mathrm{~nm}$ FinFETs $[14,15]$. In the following years, Samsung has released details on the $7 \mathrm{~nm}$ FinFET technology with EUV (extreme ultraviolet) lithography and started mass production of FinFET with higher performance and lower power consumption on October 18, $2018[16,17]$. Samsung had set a course for FinFET technology since 2016 and FinFET process

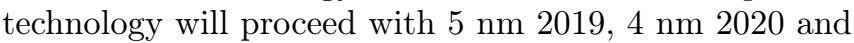
$3 \mathrm{~nm} 2021$ [18]. On January 7, 2019, Intel introduced $10 \mathrm{~nm}$ Ice Lake processors that have high- $k$ metal gate transistors with 3D structures [19].

\section{Gate dielectrics}

According to the Moore's law, it is predicted that the dimensions of the transistors will shrink every 2 years. With advancing technology, as the dimensions of the dielectric material diminish, the number of transistors per chip increases. In addition to size shrinking, performance and functionality of the new generation transistors also improve (Fig. 1). Moreover, the cost of the circuits reduces biennially $[20,21]$. As the gate length of transistors decreases, the thickness of the gate oxide layer should also decrease to maintain the same performance. However, thickness of the gate oxide layer below $1 \mathrm{~nm}$ causes high leakage currents due to the tunneling effect $[2,6]$. To use 
thicker oxide layers and maintain the same performance, $\mathrm{SiO}_{2}$ should be replaced by high dielectric constant oxides in the new generation transistors. A high $\kappa$ value provides lower equivalent oxide thickness (EOT) and higher the gate capacitance at the desired thickness. The EOT can be calculated as

$$
\mathrm{EOT}=d_{\mathrm{Hik}} \frac{K_{\mathrm{SiO}_{2}}}{K_{\mathrm{HiK}}},
$$

where $d_{\mathrm{HiK}}$ is the thickness of the dielectric layer, $K_{\mathrm{SiO}_{2}}$ is the dielectric constant of silicon dioxide and $K_{\mathrm{HiK}}$ is the dielectric constant of gate oxide.

In addition, convenient gate oxide layers must have the band offset values of at least $1 \mathrm{eV}$ in order to prevent leakage currents. High- $\kappa$ oxides with over $5 \mathrm{eV}$ band gaps tend to satisfy this value and hinder flux of electrons or holes into the oxide layers. However, $\kappa$ values of most dielectric materials are inversely proportional to the band gap value as shown in Table I [21-23].

\section{TABLE I}

Comparison of dielectric constant and band gap for various dielectric materials [24-28].

\begin{tabular}{c|c|c}
\hline \hline Dielectrics & Dielectric constant $(\kappa)$ & Band gap [eV] \\
\hline $\mathrm{Si}$ & - & 1.1 \\
$\mathrm{SiO}_{2}$ & 3.9 & 9 \\
$\mathrm{Si}_{3} \mathrm{~N}_{4}$ & 7.5 & 5 \\
$\mathrm{ZrO}_{2}$ & 25 & 5.8 \\
$\mathrm{Y}_{2} \mathrm{O}_{3}$ & 15 & 5.6 \\
$\mathrm{La}_{2} \mathrm{O}_{3}$ & 30 & 6 \\
$\mathrm{Al}_{2} \mathrm{O}_{3}$ & 10 & 8.8 \\
$\mathrm{TiO}_{2}$ & 80 & 3.5 \\
$\mathrm{Ta}_{2} \mathrm{O}_{5}$ & 22 & 4.4 \\
$\mathrm{HfO}_{2}$ & $22-25$ & $5.5-6$ \\
$\mathrm{LaAlO}_{3}$ & 30 & 5.6 \\
$\mathrm{SrZrO}_{3}$ & $24-27$ & 5.7
\end{tabular}

Optical band gap of the dielectrics can be analyzed by UV-vis spectroscopic techniques. The band gap of a semiconductor is related to absorbance and photon energy in the following Eq. (2):

$$
\alpha h \nu=B\left(h \nu-E_{g}\right)^{m}
$$

where $\alpha$ is the absorption coefficient, $h \nu$ is the photon energy, $E_{g}$ is the optical band gap, $B$ is a constant and $m$ is a constant related to different electronic transitions for direct allowed $m=1 / 2$, indirect allowed $m=2$, direct forbidden $m=3 / 2$ and indirect forbidden $m=3$ transitions. First, the graph of optical absorption coefficient $(\alpha)$ with photon energy is acquired. Then, extrapolation the straight-line part of the curves to zero absorption coefficient value reveals the optical energy band gap value [29].

Dielectric materials are preferred to have amorphous structure, because leakage current occurs more frequently in crystalline structures than in amorphous structures due to presence of grain boundaries [30].

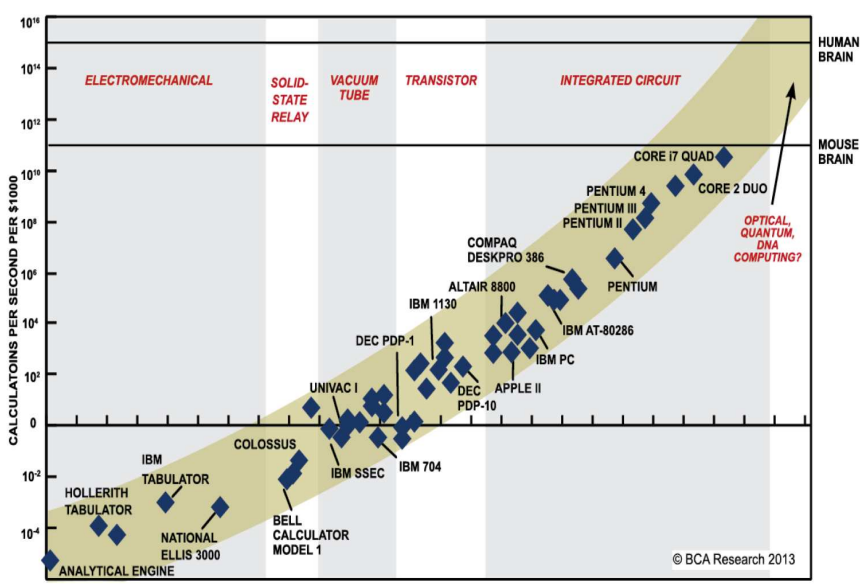

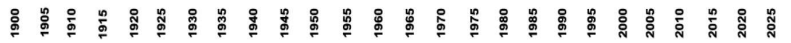

Fig. 1. Moore's law scaling [31].

The selection criteria of a new high- $\kappa$ dielectric is as follows: dielectric properties, defect chemistry, chemical suitability with the silicon channel and the gate dielectric leakage current value [21]. When these criteria are considered, alternative dielectrics can be listed as $\left(\mathrm{Ba}_{x} \mathrm{Sr}_{1-x}\right) \mathrm{TiO}_{3}$ (BST), $\mathrm{Al}_{2} \mathrm{O}_{3}, \mathrm{Y}_{2} \mathrm{O}_{3}, \mathrm{La}_{2} \mathrm{O}_{3}, \mathrm{HfO}_{2}$, $\mathrm{ZrO}_{2}, \quad \mathrm{TiO}_{2}, \quad \mathrm{Ta}_{2} \mathrm{O}_{5}$ and some nitrides, especially $\mathrm{Si}_{3} \mathrm{~N}_{4}$ [21].

BST has high dielectric constant $(\kappa \approx 100-700)$ and low leakage current density of $5 \times 10^{-8} \mathrm{~A} / \mathrm{cm}^{2}$ at $1 \mathrm{~V}$ at $30 \mathrm{~nm}$ thickness, but it reacts with the $\mathrm{Si}$ substrate to form undesirable interfacial layer [21, 32]. $\mathrm{Al}_{2} \mathrm{O}_{3}$ has many advantages such as a large band gap $(\approx 9 \mathrm{eV})$ and good thermal stability with silicon substrates [33]. $\quad \mathrm{Si}_{3} \mathrm{~N}_{4}$ has good mechanical properties and corrosion/thermal-shock resistance. However, both $\mathrm{Al}_{2} \mathrm{O}_{3}(\kappa \approx 9)$ and $\mathrm{Si}_{3} \mathrm{~N}_{4}(\kappa \approx 7)$ have low dielectric constants $[34,35]$. $\mathrm{La}_{2} \mathrm{O}_{3}$ has a high dielectric constant $(\kappa \approx 27)$ and it is thermodynamically stable with $\mathrm{Si}$, but its band gap value is small $(4.3 \mathrm{eV})$ [36]. $\quad \mathrm{TiO}_{2}$ and $\mathrm{Ta}_{2} \mathrm{O}_{5}$ have high dielectric constants $(\kappa=40-80$ and $\kappa=25$, respectively), but both are instable with silicon substrates [37-39].

The dielectric constants of materials are interrelated with the structure (i.e., amorphous and crystalline). $\mathrm{ZrO}_{2}$ and $\mathrm{HfO}_{2}$ vary from $\kappa \approx 17-47$ and $\kappa \approx 12-17$. In addition, $\mathrm{HfO}_{2}$ is more stable than $\mathrm{ZrO}_{2}$ if the interaction with the Si substrate is concerned $[40,41]$. Moreover, the leakage current of $\mathrm{HfO}_{2}\left(10^{-3} \mathrm{~A} / \mathrm{cm}^{2}\right)$ is lower than that of $\mathrm{ZrO}_{2}\left(4 \times 10^{-3} \mathrm{~A} / \mathrm{cm}^{2}\right)$ under the electric field $1 \mathrm{MV} / \mathrm{cm}$ at temperature of $550{ }^{\circ} \mathrm{C}$ [42].

$\mathrm{HfO}_{2}$ thin films have wide band gap of $\approx 5.8 \mathrm{eV}$, high dielectric constant $(\kappa \approx 25)$ and suitable band offset values relative to $\mathrm{Si}$ substrate. In addition, they have excellent thermodynamic and chemical stability with Si [43, 44]. Therefore, Hf-based oxides are the strongest candidate materials for replacing $\mathrm{SiO}_{2}$ gate dielectrics. 


\section{Hf-based high- $\kappa$ dielectrics}

$\mathrm{HfO}_{2}$ presents polymorphisms. It crystallizes in monoclinic $\mathrm{m}-\mathrm{HfO}_{2}$ structure at low temperature, which changes to tetragonal t- $\mathrm{HfO}_{2}$ upon heating and to cubic c- $\mathrm{HfO}_{2}$ at higher temperatures (Fig. 2) [45]. Experimental results showed that change in the crystal structure of $\mathrm{HfO}_{2}$ also changes the band gap. The band gaps of $\mathrm{c}-\mathrm{HfO}_{2}, \mathrm{t}-\mathrm{HfO}_{2}, \mathrm{~m}-\mathrm{HfO}_{2}$ and a- $\mathrm{HfO}_{2}$ (amorphous) are $5.53,5.79,5.65$, and $6.04 \mathrm{eV}$, respectively [30, 45].

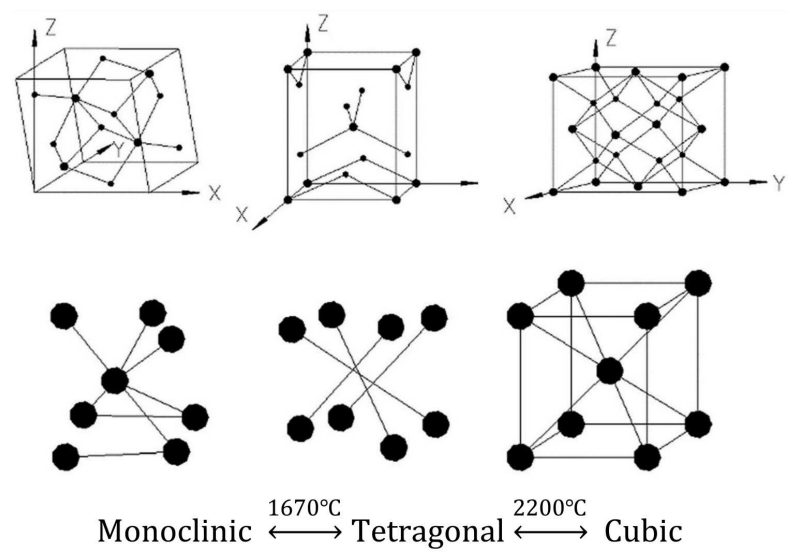

Fig. 2. Polymorphic transformation of $\mathrm{HfO}_{2}$ [46].

Generally, amorphous structures are preferred in dielectric materials, because leakage current occurs in crystalline structure due to grain boundaries. Thus, a- $\mathrm{HfO}_{2}$ is the most preferred structure in electronic and optoelectronic devices [47].

Following defects form in $\mathrm{HfO}_{2}$ (Fig. 3), interstitial oxygen $\left(\mathrm{O}_{\mathrm{i}}^{\prime \prime}=\mathrm{O}_{\mathrm{i}}^{2-}\right)$, oxygen vacancy $\left(\mathrm{V}_{\mathrm{O}}^{\prime \prime}=\mathrm{V}_{\mathrm{O}}^{2+}\right)$ and hafnium vacancy $\left(\mathrm{V}_{\mathrm{HF}}^{\prime \prime \prime \prime}=\mathrm{V}_{\mathrm{Hf}}^{4-}\right)[48]$.

- Oxygen vacancy defect chemistry in $\mathrm{Si}-\mathrm{HfO}_{2}$ heterostructure can be suggested according to Eq. (3):

$$
\mathrm{O}_{\mathrm{O}}{ }^{x} \rightarrow \mathrm{V}_{\mathrm{O}}^{\prime \prime}+2 \mathrm{e}^{\prime}+\frac{1}{2} \mathrm{O}_{2}(\mathrm{~g})
$$

- Oxygen interstitial defect chemistry in $\mathrm{Si}-\mathrm{HfO}_{2}$ heterostructure can be suggested according to Eq. (4):

$$
\frac{1}{2} \mathrm{O}_{2}(\mathrm{~g}) \rightarrow \mathrm{O}_{\mathrm{i}}^{\prime \prime}+2 \mathrm{~h}^{\prime}
$$

- Hafnium vacancy defect chemistry in $\mathrm{Si}-\mathrm{HfO}_{2}$ heterostructure can be suggested according to Eq. (5):

$$
\mathrm{O}_{2} \rightarrow \mathrm{V}_{\mathrm{Hf}}^{\prime \prime \prime \prime}+4 \mathrm{~h}+2 \mathrm{O}_{\mathrm{O}}{ }^{x} \text {. }
$$

These defects can adversely affect the performance of devices. Also, they can create an electric field which can change band offsets and disrupt its dielectric properties [49].

It is quite essential to determine thermodynamic stability of $\mathrm{HfSi}_{2}$ at the $\mathrm{HfO}_{2} / \mathrm{Si}$ interface by using isothermal sections and the isopleth calculations. This thermodynamic stability is related to the formation energy of $\mathrm{HfSiO}_{4}$. The enthalpy of formation for $\mathrm{HfSiO}_{4}$ is calculated according to Eq. (6) by using the data from Table II. The result of calculation foresees that $\mathrm{HfSi}_{2}$ is stable below $543.53 \mathrm{~K}$ [50]:

$$
\Delta H_{f}^{\mathrm{HfSiO}_{4}}=H\left(\mathrm{HfSiO}_{4}\right)-\frac{1}{2} H\left(\mathrm{HfO}_{2}\right)-\frac{1}{2} H\left(\mathrm{SiO}_{2}\right)
$$

(a)

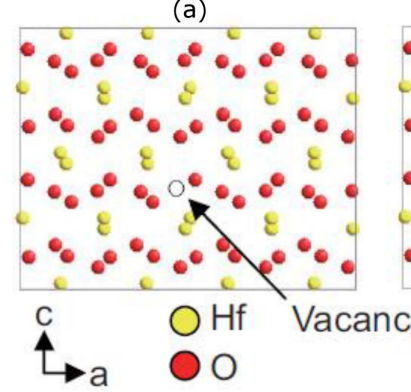

Fig. 3. Initial structures of (a) $\mathrm{HfO}_{2}$ with one oxygen vacancy and (b) $\mathrm{HfO}_{2}$ with one interstitial for quantum chemical molecular dynamics simulation [49].

\begin{tabular}{|c|c|c|c|c|c|c|}
\hline \multirow{2}{*}{ Phases } & \multirow{2}{*}{ Space group } & \multicolumn{3}{|c|}{ Lattice parameters $[\AA]$} & \multirow{2}{*}{$\begin{array}{c}\text { Total energy } \\
\text { [eV/atom] }\end{array}$} & \multirow{2}{*}{$\begin{array}{c}\Delta H^{f} \\
{[\mathrm{~kJ} /(\mathrm{mol} \text { atom })]}\end{array}$} \\
\hline & & $\mathrm{a}$ & $\mathrm{b}$ & $\mathrm{c}$ & & \\
\hline HCP_A3 (Hf) & $P 63 / m m c$ & 3.198 & 3.198 & 5.053 & -9.8320 & 0 \\
\hline Diamond_A4 (Si) & $F d \overline{3} m$ & 5.468 & 5.468 & 5.468 & -5.4315 & 0 \\
\hline $\operatorname{Gas}\left(\mathrm{O}_{2}\right)$ & - & - & - & - & -4.7936 & 0 \\
\hline$\alpha-\mathrm{Hf}\left(\mathrm{HfO}_{0.5}\right)$ & $P \overline{3} m 1$ & 3.225 & 3.225 & 5.150 & -4.7936 & -175.511 \\
\hline $\mathrm{B}-\mathrm{Hf}\left(\mathrm{HfO}_{3}\right)$ & $\operatorname{Im} \overline{3} m$ & 4.364 & 4.364 & 4.364 & -7.7253 & -161.308 \\
\hline Monoclinic $\left(\mathrm{HfO}_{2}\right)$ & $P 2_{1} / c$ & 5.135 & 5.194 & 5.134 & -10.2101 & -360.563 \\
\hline Quartz $\left(\mathrm{SiO}_{2}\right)$ & $P 3_{2} 21$ & 5.007 & 5.007 & 5.496 & -7.9581 & -284.809 \\
\hline $\mathrm{HfSiO}_{4}$ & $I 4_{1} / a m d$ & 6.616 & 6.616 & 6.004 & -9.1024 & -324.453 \\
\hline
\end{tabular}

TABLE II

First-principles calculation results of pure elements, hypothetical compounds $\left(\alpha, \beta\right.$-Hf), and stable compounds $\left(\mathrm{HfO}_{2}\right.$, $\mathrm{SiO}_{2}$, and $\mathrm{HfSiO}_{4}$ ) [50]. 


\subsection{Fabrication methods}

$\mathrm{HfO}_{2}$ thin films have been synthesized by chemical vapor deposition (CVD) [51], atomic layer deposition (ALD) [52], pulsed laser deposition (PLD) [53], plasma oxidation [54], electron beam evaporation [55], molecular beam epitaxy [56], RF magnetron sputtering [57] and solgel method [58]. As a precursor, $\mathrm{HfOCl}_{2}$ (hafnium(IV) oxychloride) [59], Hf (O-i-Pr) 4 (hafnium isopropoxide) [60], $\mathrm{Hf}\left(\mathrm{OC}_{2} \mathrm{H}_{5}\right)_{4}$ (hafnium tetra-ethoxide) [61], $\mathrm{HfCl}_{4}$ (hafnium tetra-chloride) [58] were used.

Gopalan et al. indicated that $\mathrm{HfO}_{2}$ films were deposited by CVD on p-type Si (100) substrates. Dielectric constant and the EOT of $\mathrm{HfO}_{2}$ thin films annealed at $600{ }^{\circ} \mathrm{C}$ and $700^{\circ} \mathrm{C}$ were measured as $22.18 \mathrm{~nm}$, $16.95 \mathrm{~nm}$, and $2.45 \mathrm{~nm}, 2.73 \mathrm{~nm}$, respectively [62]. Sayan et al. showed that leakage current densities of $\mathrm{HfO}_{2}$ thin films as-deposited and annealed (crystallized) at $800^{\circ} \mathrm{C}$ by using CVD technique were $7.4 \times 10^{-8} \mathrm{~A} / \mathrm{cm}^{2}$ and $2.6 \times 10^{-5} \mathrm{~A} / \mathrm{cm}^{2}$ at $1 \mathrm{~V}$, respectively [63].

Hackley and Gougousi deposited $\mathrm{HfO}_{2}$ films by ALD using the tetrakis ethylmethyl amino hafnium (TEMAHf) as a precursor which were annealed at different temperatures. The root-mean-square (RMS) roughness values of $\mathrm{HfO}_{2}$ films were between 0.9 and $1.7 \mathrm{~nm}$ annealed at different temperatures $\left(400,700\right.$ and $\left.900^{\circ} \mathrm{C}\right)$. Increasing annealing temperature significantly increased surface roughness. According to XRD and FTIR analyses, the films annealed at $400^{\circ} \mathrm{C}$ were amorphous, while at $600{ }^{\circ} \mathrm{C}$ films crystallized to monoclinic phase [64].

Wang et al. have synthesized $\mathrm{HfO}_{2}$ films prepared by pulsed laser deposition on $\mathrm{Si}(100)$ substrate in air and $\mathrm{N}_{2}$ atmosphere. Dielectric constant, band gap, and EOT of the films annealed at $500^{\circ} \mathrm{C}$ in air were $\kappa=40.8$, $E_{g}=5.30 \mathrm{eV}$ and $8.68 \mathrm{~nm}$, respectively. These values changed to $\kappa=25.1, E_{g}=5.57 \mathrm{eV}$ and $7.44 \mathrm{~nm}$, when films annealed at $500^{\circ} \mathrm{C}$ in $\mathrm{N}_{2}$ [65]. In another study, Ying et al. have investigated electrical properties of polycrystalline monoclinic $\mathrm{HfO}_{2}$ dielectrics prepared by pulsed laser deposition. The dielectric constants for as-deposited and $700^{\circ} \mathrm{C}$ annealed $\mathrm{HfO}_{2}$ films were 12.2 and 16.5, respectively. Leakage current densities were measured as $9.8 \times 10^{-8}, 9.2 \times 10^{-7} \mathrm{~A} / \mathrm{cm}^{2}$ under electric

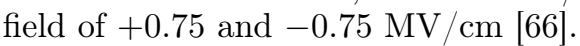

$\mathrm{He}$ et al. have demonstrated $\mathrm{HfO}_{2}$ films grown on $\mathrm{Si}(100)$ by plasma oxidation. Characterization results are summarized in Table III. Both thickness and band gap of the films decreased with increase of annealing temperature [54]. Li et al. found as the highest dielectric constant of $\kappa=22$ of $\mathrm{HfO}_{2}$ when the film was annealed at $500{ }^{\circ} \mathrm{C}$ by plasma oxidation [67]. Yamamoto et al. have analyzed the relation between leakage current density and EOT of $\mathrm{HfO}_{2}$ films prepared by remote plasma oxidation. The results showed as the EOT increasing, the leakage current density decreased to $1.7 \times 10^{-6} \mathrm{~A} / \mathrm{cm}^{2}$ [68].

Ramzan et al. have found that optical band gap energy of e-beam evaporated $\mathrm{HfO}_{2}$ at different substrate temperatures $\left(25-120^{\circ} \mathrm{C}\right)$ were strongly dependent on the morphology and grain orientation. There was no significant
TABLE III

Electrical results on as-deposited and annealed at 700 and $800^{\circ} \mathrm{C}$ samples [54].

\begin{tabular}{|c|c|c|}
\hline $\begin{array}{c}\text { Annealing } \\
\text { temperature }\end{array}$ & $\mathrm{t}-\mathrm{HfO}_{2}[\mathrm{~nm}]$ & $E_{g}[\mathrm{eV}]$ \\
\hline as-deposited & 43.1 & 5.77 \\
\hline $700^{\circ} \mathrm{C}$ & 35.0 & 5.65 \\
\hline $800^{\circ} \mathrm{C}$ & 34.2 & 5.56 \\
\hline
\end{tabular}

difference in the optical band gap value of the films as the substrate temperature changes. The optical band gap energy of as-deposited and annealed $\mathrm{HfO}_{2}$ films were between 3.4 and $3.65 \mathrm{eV}$, and $4.36-4.45 \mathrm{eV}$, respectively [69]. It was shown that dielectric constant, leakage current density, and EOT of the films deposited by electron beam evaporation were $\kappa=21.2$, $J=2 \times 10^{-3} \mathrm{~A} / \mathrm{cm}^{2}$ at $1 \mathrm{~V}$ and $0.65 \mathrm{~nm}$, respectively [70].

Leakage current density and EOT of $\mathrm{HfO}_{2}$ thin films prepared by laser molecular beam epitaxy (LMBE) were characterized by $\mathrm{Lu}$ et al. [56]. It was found that leakage current density and EOT of $\mathrm{HfO}_{2}$ thin films were $1.5 \times 10^{-2} \mathrm{~A} / \mathrm{cm}^{2}$ (at $1 \mathrm{~V}$ ) and $1.3 \mathrm{~nm}$, respectively. Yan et al. prepared $\mathrm{HfO}_{2}$ thin films by atomic oxygen assisted molecular beam epitaxy. In this study, dielectric constant before annealing was 19, which decreased to 17 after annealing [71].

Nath and Roy investigated the effects of annealing temperature on $\mathrm{HfO}_{2}$ thin films grown by radio frequency sputtering. From the $I-V$ analyses, the lowest leakage current density of $1.5 \times 10^{-5} \mathrm{~A} / \mathrm{cm}^{2}$ was measured at $-2 \mathrm{~V}$ at $600{ }^{\circ} \mathrm{C}$. According to $C-V$ analyses at the same annealing temperature, the highest dielectric constant $\kappa=14$ and the lowest EOT=1.3 nm were obtained [72].

Jin et al. investigated the optical and electrical properties in relation to annealing temperatures of $\mathrm{HfO}_{2}$ thin films deposited on $n$-type $\mathrm{Si}$ and quartz substrates by using sol-gel method. The smallest EOT was determined as $3.10 \mathrm{~nm}$ when $\mathrm{HfO}_{2}$ thin films were annealed at $400{ }^{\circ} \mathrm{C}$ [43]. $\quad \mathrm{HfO}_{2}$ thin films were synthesized on $p$-type Si (100) by sol-gel method with high purity by Leu et al. [73]. The results indicated that the thickness and surface roughness values of $\mathrm{HfO}_{2}$ thin films annealed at $900^{\circ} \mathrm{C}$ were $8.2 \mathrm{~nm}, 10.4 \mathrm{~nm}$ and $0.283 \mathrm{~nm}, 0.257 \mathrm{~nm}$, respectively. Crystallization temperature of the $\mathrm{HfO}_{2}$ films deposited by sol-gel methods was observed between 500 and $550^{\circ} \mathrm{C}$ by Nishide et al. [58].

According to Table IV, the best results of thin films derived from different coating methods are as follows. The highest value of dielectric constant is obtained with pulsed laser deposition method. The lowest values of EOT and leakage current are observed with e-beam evaporation and atomic layer deposition methods. Among them, sol-gel method results in high-quality films in various shapes, sizes and forms. It is also a simple technique, with which the components of a multi-layered structure can be easily controlled. In addition, the process takes place at low temperatures leading to lower cost. 
Summary of results of different coating methods [43, 58, 62-76].

TABLE IV

\begin{tabular}{|c|c|c|c|}
\hline Methods & Advantages & Disadvantages & Electrical properties \\
\hline CVD & $\begin{array}{l}\text { large area growth, good } \\
\text { composition control, film } \\
\text { uniformity, excellent confor- } \\
\text { mal step coverage }\end{array}$ & $\begin{array}{l}\text { restricted deposit temper- } \\
\text { ature, difficult controlling } \\
\text { composition, composition } \\
\text { impurity, high cost }\end{array}$ & $\begin{array}{l}\kappa=17-23 \\
J=7.4 \times 10^{-8} \mathrm{~A} / \mathrm{cm}^{2} \text { at } 1 \mathrm{~V} \\
\mathrm{EOT}=2.73 \mathrm{~nm} \text { at } 700^{\circ} \mathrm{C}\end{array}$ \\
\hline ALD & $\begin{array}{l}\text { atomic level control of the } \\
\text { film thickness, excellent con- } \\
\text { formal step coverage, ultra- } \\
\text { thin films, deposit at low } \\
\text { temperature }\end{array}$ & very slow growth rate & $\begin{array}{l}\kappa=12-20 \\
J=2.2 \times 10^{-9} \mathrm{~A} / \mathrm{cm}^{2} \text { at } 1 \mathrm{~V} \\
\mathrm{EOT}=0.5 \mathrm{~nm} \text { at } 800^{\circ} \mathrm{C}\end{array}$ \\
\hline PLD & $\begin{array}{l}\text { simplicity, flexibility, main- } \\
\text { taining the target stoichiom- } \\
\text { etry, large deposition rate, } \\
\text { low growth temperature }\end{array}$ & $\begin{array}{l}\text { relatively difficult to control } \\
\text { film composition }\end{array}$ & $\begin{array}{l}\kappa=25-40 \\
J=9.8 \times 10^{-8} \mathrm{~A} / \mathrm{cm}^{2} \text { at } 0.75 \mathrm{~V} \\
\mathrm{EOT}=7.44 \mathrm{~nm} \text { at } 500^{\circ} \mathrm{C} \\
E_{g}=5.57\end{array}$ \\
\hline plasma oxidation & $\begin{array}{l}\text { low growth temperature, } \\
\text { high quality, easy control- } \\
\text { lable growth }\end{array}$ & $\begin{array}{l}\text { difficult controlling compo- } \\
\text { sition }\end{array}$ & $\begin{array}{l}\kappa=22 \\
J=2.7 \mathrm{~A} / \mathrm{cm}^{2} \text { at }-1 \mathrm{~V} \\
\mathrm{EOT}=0.65 \mathrm{~nm} \text { at } 600^{\circ} \mathrm{C} \\
E_{g}=5.77 \mathrm{eV}\end{array}$ \\
\hline e-beam evaporation & $\begin{array}{l}\text { control of deposition rates, } \\
\text { excellent material utiliza- } \\
\text { tion, freedom from contam- } \\
\text { ination, good purity }\end{array}$ & $\begin{array}{l}\text { higher surface roughness, } \\
\text { relatively difficult to control } \\
\text { film }\end{array}$ & $\begin{array}{l}\kappa=21 \\
J=2 \times 10^{-3} \mathrm{~A} / \mathrm{cm}^{2} \text { at } 1 \mathrm{~V} \\
\mathrm{EOT}=10.9 \AA \text { at } 400{ }^{\circ} \mathrm{C} \\
E_{g}=3.65 \mathrm{eV}\end{array}$ \\
\hline molecular beam epitaxy & $\begin{array}{l}\text { atomic level control of the } \\
\text { film thickness, high purity }\end{array}$ & slow growth rate & $\begin{array}{l}\kappa=17-19 \\
J=1.5 \times 10^{-2} \mathrm{~A} / \mathrm{cm}^{2} \text { at } 1 \mathrm{~V} \\
\mathrm{EOT}=1.3 \mathrm{~nm} \text { at } 500^{\circ} \mathrm{C}\end{array}$ \\
\hline RF sputtering & $\begin{array}{l}\text { lower contaminants, control- } \\
\text { lable growth, low tempera- } \\
\text { ture process, compositional } \\
\text { consistency, low cost }\end{array}$ & $\begin{array}{l}\text { sputtered target plasma in- } \\
\text { duced damage, difficult to } \\
\text { deposited complex shape }\end{array}$ & $\begin{array}{l}\kappa=14 \\
J=1.5 \times 10^{-5} \mathrm{~A} / \mathrm{cm}^{2} \text { at }-2 \mathrm{~V} \\
\mathrm{EOT}=1.3 \mathrm{~nm} \text { at } 600^{\circ} \mathrm{C}\end{array}$ \\
\hline
\end{tabular}

\subsection{Commonly used dopants in $\mathrm{HfO}_{2}$}

Doping of $\mathrm{HfO}_{2}$ gate dielectric provides many advantageous properties. Therefore, $\mathrm{HfO}_{2}$ has been doped with elements such as N, Si, Al forming mostly interstitial defects or Ti and Ta forming substitutional defects $[77,78]$.

\subsection{1. $N$-doping}

It has been observed that thermal and electrical properties of $\mathrm{HfO}_{2}$ are improved by $\mathrm{N}$ doping. Nitrogen incorporation increases the crystallization temperature enabling the application of higher annealing temperatures [79]. The valence band offset and the conduction band offset of high- $\kappa$ gate dielectrics should be larger than $1 \mathrm{eV}$. Liu et al. deposited $\mathrm{HfO}_{x} \mathrm{~N}_{y}$ samples on $\mathrm{Si}(100)$ by using radio-frequency reactive magnetron sputtering and have demonstrated that valence band offset and conduction band offset of the $\mathrm{HfO}_{x} \mathrm{~N}_{y}$ increases with annealing temperature. Table V summarizes the effect of annealing temperature on the band offsets of $\mathrm{HfO}_{x} \mathrm{~N}_{y}$ films [80].
TABLE V

Conduction band offsets and valence band offset of $\mathrm{HfO}_{x} \mathrm{~N}_{y}$ films: as-deposited, $500^{\circ} \mathrm{C}$, and $800^{\circ} \mathrm{C}$ [80]

\begin{tabular}{c|c|c}
\hline \hline $\begin{array}{c}\text { Annealing } \\
\text { temperature }\end{array}$ & $\begin{array}{c}\text { Conduction } \\
\text { band offsets }\left(\Delta E_{c}\right)\end{array}$ & $\begin{array}{c}\text { Valence } \\
\text { band offset }\left(\Delta E_{v}\right)\end{array}$ \\
\hline as-deposited & 0.85 & 2.46 \\
$500^{\circ} \mathrm{C}$ & 1.20 & 2.73 \\
$800^{\circ} \mathrm{C}$ & 1.25 & 2.95
\end{tabular}

\subsubsection{Si-doping}

$\mathrm{HfSiO}_{x}$ gate dielectrics, deposited by co-sputtering of hafnium oxide and silicon, in different annealing temperatures were prepared by Lim et al. [81]. In this article, $\mathrm{HfSiO}_{x}$ thin films are thermally more stable than $\mathrm{HfO}_{2}$ because $\mathrm{Si}$ inhibits crystallization of $\mathrm{HfO}_{2} \cdot \mathrm{HfSiO}_{x}$ films crystallized above $800^{\circ} \mathrm{C}$ whereas crystallization of $\mathrm{HfO}_{2}$ occurred at $500^{\circ} \mathrm{C}$. Six different defects form in $\mathrm{HfSiO}_{x}$; oxygen vacancy $\left(\mathrm{V}_{\mathrm{O}}^{2+}\right)$, hafnium vacancy $\left(\mathrm{V}_{\mathrm{Hf}}^{2-}, \mathrm{V}_{\mathrm{Hf}}^{4-}\right)$, 
silicon vacancy $\left(\mathrm{V}_{\mathrm{Si}}^{2-}, \mathrm{V}_{\mathrm{Si}}^{4-}\right)$, oxygen interstitial $\left(\mathrm{O}_{\mathrm{i}}^{2-}\right)$, hafnium interstitial $\left(\mathrm{Hf}_{\mathrm{i}}^{4+}\right)$ and silicon interstitial $\left(\mathrm{Si}_{\mathrm{i}}^{4+}\right)$. In the presence of $\mathrm{V}_{\mathrm{Hf}}^{4-}, \mathrm{V}_{\mathrm{Si}}^{4-}, \mathrm{V}_{\mathrm{O}}^{2+}$ defects, the conduction band offset reduces and the leakage current density increases [82].

\subsubsection{Al-doping}

When $\mathrm{Al}$ is added to $\mathrm{HfO}_{2}$ dielectrics, Hf atom is substituted by an $\mathrm{Al}$ atom forming the defect $\left(\mathrm{Al}_{\mathrm{Hf}}^{\prime}=\right.$ $\mathrm{Al}_{\mathrm{Hf}}^{-}$) [83]. Interstitial $\mathrm{Al}$ defect can be written by

$$
\mathrm{Al}_{2} \mathrm{O}_{3} \stackrel{\mathrm{HfO}_{2}}{\longrightarrow} 2 \mathrm{Al}_{\mathrm{Hf}}^{\prime}+\mathrm{V}_{\mathrm{O}}^{\prime \prime}+3 \mathrm{O}_{\mathrm{O}}{ }^{x}
$$

$\mathrm{Lu}$ et al. deposited $\mathrm{HfO}_{2}$ and $\mathrm{HfAlO}$ thin films on $n$-type Si-doped GaAs wafers by atomic layer deposition and stated that effective dielectric constant $\left(\kappa_{\text {eff }}\right)$ of $\mathrm{HfO}_{2}$ increases, while EOT decreases by the addition of $\mathrm{Al}_{2} \mathrm{O}_{3}$ (Table VI) [84].

\subsubsection{Ti-doping}

$\mathrm{Ti}$ and Hf have the same valence numbers as they both belong to group $4 \mathrm{~B}$ in the periodic table [78]. The possible defect chemistries can be written according to Eqs. (8)-(11):

$$
\begin{aligned}
& \mathrm{TiO}_{2} \stackrel{\mathrm{HfO}_{2}}{\longrightarrow} \mathrm{Ti}_{\mathrm{Hf}}{ }^{x}+2 \mathrm{O}_{\mathrm{O}}{ }^{x}, \\
& \mathrm{O}_{\mathrm{O}}{ }^{x} \rightarrow \mathrm{V}_{\mathrm{O}}^{\prime \prime}+2 \mathrm{e}^{\prime}+\frac{1}{2} \mathrm{O}_{2}(\mathrm{~g}), \\
& \frac{1}{2} \mathrm{O}_{2}(\mathrm{~g}) \rightarrow \mathrm{O}_{\mathrm{i}}^{\prime \prime}+2 \mathrm{~h}^{\prime},
\end{aligned}
$$

$$
\mathrm{O}_{2} \rightarrow \mathrm{V}_{\mathrm{Ti}}^{\prime \prime \prime \prime}+4 \mathrm{~h}^{\prime}+2 \mathrm{O}_{\mathrm{O}}{ }^{x} .
$$

Microstructures of $\mathrm{HfO}_{2}, \mathrm{TiO}_{2}$ and $\mathrm{HfO}_{2}-\mathrm{TiO}_{2}$ films deposited by reactive magnetron sputtering were investigated by Mazur et al. [85]. SEM images of $\mathrm{HfO}_{2}$, $\left(\mathrm{Hf}_{0.83} \mathrm{Ti}_{0.17}\right) \mathrm{O}_{x},\left(\mathrm{Hf}_{0.72} \mathrm{Ti}_{0.28}\right) \mathrm{O}_{x},\left(\mathrm{Hf}_{0.55} \mathrm{Ti}_{0.45}\right) \mathrm{O}_{x}$ and $\mathrm{TiO}_{2}$ thin films are shown in Fig. 4. It can be seen that as the ratio of $\mathrm{Ti}$ composition in the thin films increases, surface morphology becomes more homogeneous and smoother. From SEM images, grain sizes of $\mathrm{HfO}_{2}$, $\left(\mathrm{Hf}_{0.83} \mathrm{Ti}_{0.17}\right) \mathrm{O}_{x},\left(\mathrm{Hf}_{0.72} \mathrm{Ti}_{0.28}\right) \mathrm{O}_{x},\left(\mathrm{Hf}_{0.55} \mathrm{Ti}_{0.45}\right) \mathrm{O}_{x}$ and $\mathrm{TiO}_{2}$ thin films can be observed as $20-30 \mathrm{~nm}, 25-95 \mathrm{~nm}$, 15-25 $\mathrm{nm}$ and 30-150 nm, respectively.

$\mathrm{HfTiO}$ thin films coated on silicon $p$-type layer annealed at $400^{\circ} \mathrm{C}, 500^{\circ} \mathrm{C}, 600^{\circ} \mathrm{C}$ and $700^{\circ} \mathrm{C}$ by radio frequency (RF) magnetron co-sputtering were compared by Ye et al. [86]. HfTiO thin film annealed at $600^{\circ} \mathrm{C}$ has the lowest leakage current $3.1 \times 10^{-6} \mathrm{~A} / \mathrm{cm}^{2}$ at $-1 \mathrm{~V}$, EOT of $0.8 \mathrm{~nm}$ and the highest $\kappa$ value of 45.9 .

\section{TABLE VI}

Comparison of effective dielectric permittivity and equivalent oxide thickness for $\mathrm{HfO}_{2}$ and HfAlO dielectrics [84].

\begin{tabular}{c|c|c}
\hline \hline Dielectrics & $\kappa_{\text {eff }}$ & EOT [nm] \\
\hline $\mathrm{HfAlO}$ & 13.21 & 2.63 \\
$\mathrm{HfO}_{2}$ & 3.89 & 8.28
\end{tabular}
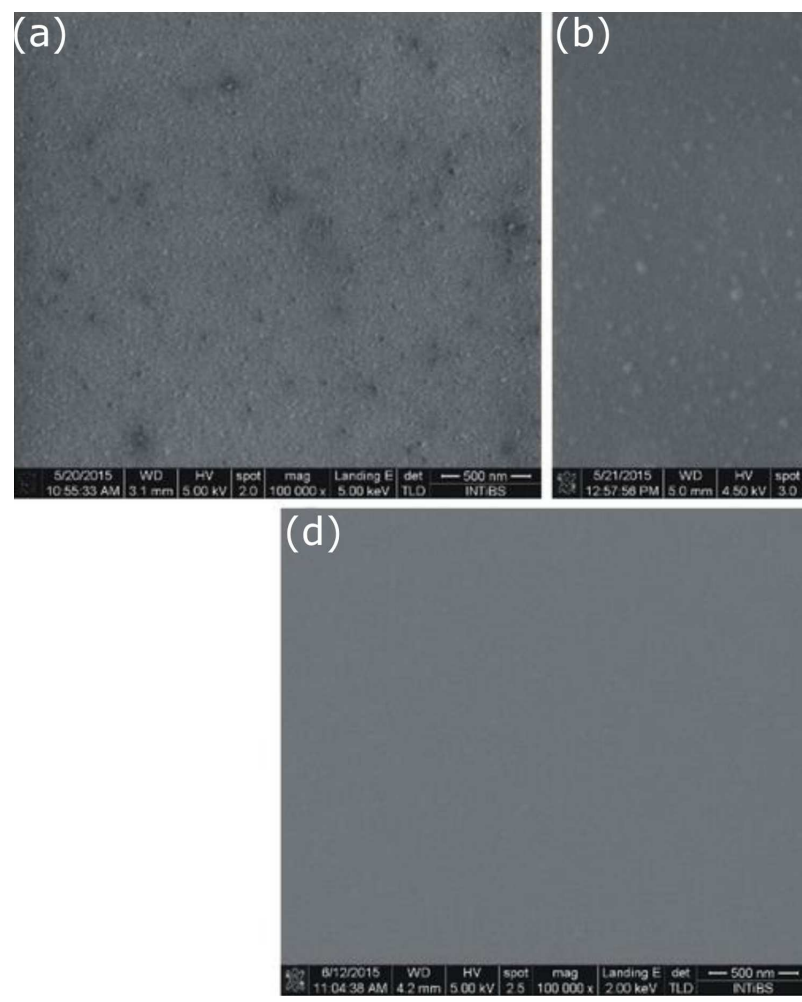
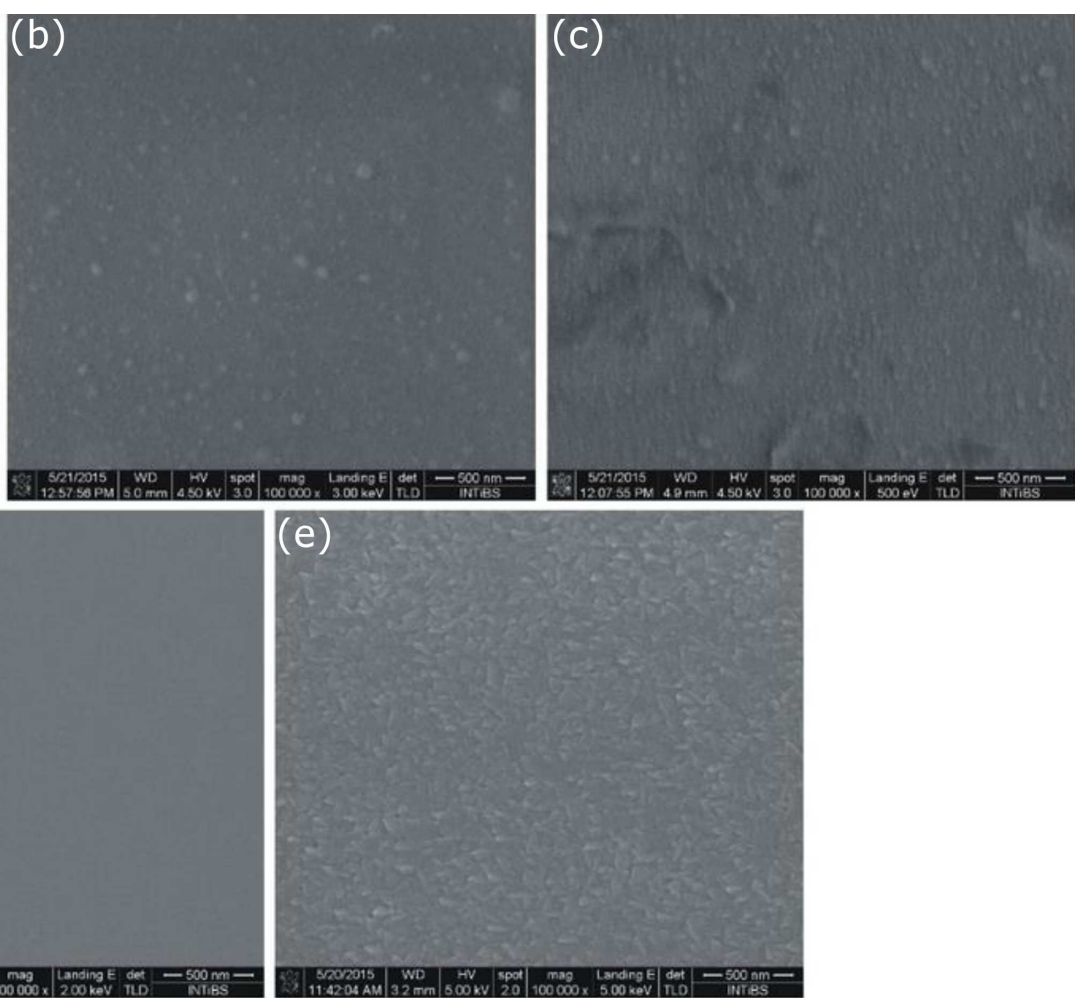

Fig. 4. SEM images of the surface of: (a) $\mathrm{HfO}_{2}$, (b) $\left(\mathrm{Hf}_{0.83} \mathrm{Ti}_{0.17}\right) \mathrm{O}_{x}$, (c) $\left(\mathrm{Hf}_{0.72} \mathrm{Ti}_{0.28}\right) \mathrm{O}_{x}$, (d) $\left(\mathrm{Hf}_{0.55} \mathrm{Ti}_{0.45}\right) \mathrm{O}_{x},(\mathrm{e})$ $\mathrm{TiO}_{2}$ thin films [85]. 


\subsubsection{Ta-doping}

Ta introduction into $\mathrm{HfO}_{2}$ films has significantly improved crystallization temperature. $\mathrm{Yu}$ et al. [87] have stated that crystallization temperature of HfTaON thin films deposited by a dual ion beam sputtering deposition technique (DIBSD) is above $1100^{\circ} \mathrm{C}$, while $\mathrm{HfO}_{2}$ crystallizes at $\approx 400^{\circ} \mathrm{C}$. Ta-doped $\mathrm{HfO}_{2}$ creates substitutional Ta incorporated in $\mathrm{HfO}_{2}$ [66] and defect chemistry is likely as follows:

$$
\mathrm{Ta}_{2} \mathrm{O}_{5} \rightarrow 2 \mathrm{Ta}_{\mathrm{Hf}}^{\prime \prime}+\mathrm{O}_{\mathrm{i}}^{\prime \prime}+4 \mathrm{O}_{\mathrm{O}}{ }^{x}
$$

HfTaO thin films with varying Ta composition $(20 \%$, $30 \%, 40 \%$, and 50\%) were co-sputtered with different annealing temperatures in $\mathrm{N}_{2}$ atmosphere by Zhang et al. [88]. The results confirmed that as Ta composition in HfTaO thin films is increased, crystallization temperature increases up to 40 at.\% (Table VII).

\section{TABLE VII}

Crystallization temperature of $\mathrm{HfTaO}$ with various Ta contents [88].

\begin{tabular}{c|c}
\hline \hline Ta composition [\%] & $\begin{array}{c}\text { Crystallization } \\
\text { temperature }\left[{ }^{\circ} \mathrm{C}\right]\end{array}$ \\
\hline 15 & 600 \\
20 & 600 \\
30 & 800 \\
40 & 900 \\
43 & 900 \\
5 & 800
\end{tabular}

\section{Conclusion}

This article has reviewed significant historical developments of high- $\kappa$ materials and latest progress in Hf-based high- $\kappa$ gate dielectric fabrication methods and commonly used dopants in $\mathrm{HfO}_{2}$. Mass-production of $45 \mathrm{~nm}$ chips with high- $\kappa /$ metal gates started in 2007 . Then, $22 \mathrm{~nm}$ chips, using high- $\kappa$ gate dielectrics, were demonstrated based on 3D tri-gate transistor architecture in 2011. At the year of $2019,10 \mathrm{~nm}$ processors with high- $\kappa$ metal gate transistors with $3 \mathrm{D}$ structures became commercially available. The processor manufacturers had set a course to decrease the gate length to smaller values in the following years. There is still demand for gate dielectrics with better properties and conquest to find new materials will not be concluded in the next few years.

\section{References}

[1] D. Misra, H. Iwai, H. Wong, Interface 14, 30 (2005).

[2] M. Salmani-Jelodar, H. Ilatikhameneh, S. Kim, K. Ng, G. Klimeck, IEEE Trans. Nanotechnol. 15, 904 (2016).

[3] S.C. Lo, Y. Li, J.H. Tsai, WSEAS Trans. Electron. 1, 170 (2004)
[4] C.F. Shih, C.Y. Hsiao, Y.C. Hsiao, B.C. Chen, C.C. Leu, Thin Solid Films 556, 291 (2014).

[5] Thermo Scientific, "Characterization of high- $\kappa$ dielectric materials on silicon using angle resolved XPS", 2004.

[6] J. Robertson, Solid-State Electron. 49, 283 (2005).

[7] A. Navrotsky, S.V. Ushakov, Materials Fundamentals of Gate Dielectrics, Eds. A.A. Demkov, A. Navrotsky, USA 2005, p. 56

[8] B.R. Kumar, T.S. Rao, Int. J. Pure Appl. Sci. Technol. 4, 105 (2011).

[9] J.N. Matthews, Phys. Today 61, 25 (2008).

[10] N. Kazuo, Dry Etching Technology for Semiconductors, Springer Int. Publ., Cham 2015, p. 101.

[11] Intel, $22 \mathrm{~nm}$ Technology.

[12] C. Auth, C. Allen, A. Blattner, et al., in: 2012 Symp. on VLSI Technology (VLSIT), IEEE, 2012, p. 131.

[13] R.S. Rathore, A.K. Rana, Superlatt. Microstruct. 113, 213 (2018).

[14] Samsung, The easy guide to a semiconductor: Why the $10 \mathrm{~nm}$ FinFET Process?.

[15] Samsung Newsroom, Samsung Launches Premium Exynos 9 Series Processor Built on the World's First $10 \mathrm{~nm}$ FinFET Process Technology.

[16] D. Ha, C. Yang, J. Lee, et al., in: 2017 Symp. on VLSI Technology, IEEE, 2017, p. T68.

[17] Samsung Newsroom, Samsung Electronics Starts Production of EUV-based $7 \mathrm{~nm}$ LPP Process.

[18] Next Big Future, Samsung process roadmap $7 \mathrm{~nm}$ 2018, $5 \mathrm{~nm} \mathrm{2019,} 4 \mathrm{~nm} 2020$ and $3 \mathrm{~nm} 2021$.

[19] OC3D.NET, Intel's $10 \mathrm{~nm}$ Ice Lake Processor to Release This Year with Sunny Cove Cores.

[20] G.E. Moore, SPIE Milestone Series MS 178, 179 (2004).

[21] A.I. Kingon, J.P. Maria, S.K. Streiffer, Nature 406 1032 (2000).

[22] A.P. Huang, P.K. Chu, Z.C. Yang, in: Advances in Solid State Circuit Technologies, Ed. P.K. Chu, InTech, Rijeka 2010, p. 333.

[23] J. Robertson, J. Vac. Sci. Technol. B 18, 1785 (2000).

[24] Q. Zeng, A.R. Oganov, A.O. Lyakhov, C. Xie, X. Zhang, J. Zhang, Q. Zhu, B. Wei, I. Grigorenko, L. Zhang, L. Cheng, Acta Crystallogr. C 70, 76 (2014).

[25] J.P. Locquet, C. Marchiori, M. Sousa, J. Fompeyrine, J. Seo, J. Appl. Phys. 100, 051610 (2006).

[26] J.C. Pravin, D. Nirmal, P. Prajoon, J. Ajayan, Physica E 83, 95 (2016).

[27] X.B. Lu, G.H. Shi, J.F. Webb, Z.G. Liu, Appl. Phys. A 77, 481 (2003).

[28] W. Chen, W. Ren, Y. Zhang, M. Liu, Z.G. Ye, Ceram. Int. 41, S278 (2015).

[29] H.P. Kumar, S. Vidya, S.S. Kumar, C. Vijayakumar, S. Solomon, J.K. Thomas, J. Asian Ceram. Soc. 3, $64(2015)$

[30] M.C. Cheynet, S. Pokrant, F.D. Tichelaar, J.L. Rouvière, J. Appl. Phys. 101, 054101 (2007).

[31] Extremetech, What is Moore's law?, 2015. 
[32] T. Kuroiwa, Y. Tsunemine, T. Horikawa, T. Makita, J. Tanimura, N. Mikami, K. Sato, Jpn. J. Appl. Phys. 33, 5187 (1994).

[33] R.L. Nigro, E. Schilirò, G. Greco, P. Fiorenza, F. Roccaforte, Thin Solid Films 617, 138 (2016).

[34] S.J. Lee, S. Baek, Ceram. Int. 42, 9921 (2016).

[35] Y. Xia, Y.P. Zeng, D. Jiang, Ceram. Int. 35, 1699 (2009).

[36] J.B. Cheng, A.D. Li, Q.Y. Shao, H.Q. Ling, D. Wu Y. Wang, Y. Bao, M. Wang, G.Z. Liu, N.B. Ming, Appl. Surf. Sci. 233, 91 (2004).

[37] M.K. Bera, C.K. Maiti, Mater. Sci. Semicond. Process. 9, 909 (2006).

[38] C.E. Kim, I. Yun, Appl. Surf. Sci. 258, 3089 (2012).

[39] M. Houssa, L. Pantisano, L.Å. Ragnarsson, R. Degraeve, T. Schram, G. Pourtois, S.D. Gendt, G. Groeseneken, M.M. Heyns, Mater. Sci. Eng. R $\mathbf{5 1}, 37$ (2006)

[40] A. Salaün, H. Grampeix, J. Buckley, C. Mannequin, C. Vallée, P. Gonon, S. Jeannot, C. Gaumer, M. GrosJean, V. Jousseaum, Thin Solid Films 525, 20 (2012).

[41] W. Zheng, K.H. Bowen, J. Li, I. Dabkowska, M. Gutowski, J. Phys. Chem. A 109, 11521 (2005).

[42] H. Shimizu, T. Nishide, in: Advances in Crystallization Processes, Ed. Y. Mastai, InTech, Rijeka 2012, Ch. 13.

[43] P. Jin, G. He, D. Xiao, J. Gao, M. Liu, J. Lv, Y. Liu, M. Zhang, P. Wang, Z. Sun, Ceram. Int. 42, 6761 (2016).

[44] S.S. Jiang, G. He, J. Gao, D. Q. Xiao, P. Jin, W.D. Li, J.G. Lv, M. Liu, Y.M. Liu, Z.Q. Sun, Ceram. Int. 42 11640 (2016)

[45] F.M. Li, B.C. Bayer, S. Hofmann, J.D. Dutson, S.J. Wakeham, M.J. Thwaites, W.I. Milne, A.J. Flewitt, Appl. Phys. Lett. 98, 252903 (2011).

[46] Y. Wan, X. Zhou, RSC Advances 7, 7763 (2017).

[47] J.M. Khoshman, A. Khan, M.E. Kordesch, Surf. Coat. Technol. 202, 2500 (2008).

[48] A.S. Foster, F.L. Gejo, A.L. Shluger, R.M. Nieminen, Phys. Rev. B 65, 174117 (2002).

[49] K. Suzuki, H. Miura, Simulat. Semicond. Process. Dev. 2007, 165 (2007).

[50] D. Shin, R. Arróyave, Z.K. Liu, Calphad 30, 375 (2006).

[51] K.J. Choi, W.C. Shin, J.B. Park, S.G. Yoon, Integrat. Ferroelectr. 48, 13 (2002).

[52] R. Gupta, R. Rajput, R. Prasher, R. Vaid, Solid State Sci. 59, 7 (2016).

[53] H. Ikeda, S. Goto, K. Honda, M. Sakashita, A. Sakai, S. Zaima, Y. Yasuda, Jpn. J. Appl. Phys. 41, 2476 (2002).

[54] G. He, L.Q. Zhu, M. Liu, Q. Fang, L.D. Zhang, Appl. Surf. Sci. 253, 3413 (2007).

[55] Y. Wang, Z. Lin, X. Cheng, H. Xiao, F. Zhang, S. Zou, Appl. Surf. Sci. 228, 93 (2004).

[56] Y.K. Lu, X.F. Chen, W. Zhu, R. Gopalkrishnan, J. Mater. Sci. Mater. Electron. 17, 685 (2006).

[57] A. Vinod, M.S. Rathore, N.S. Rao, Vacuum 155, 339 (2018).
[58] T. Nishide, S. Honda, M. Matsuura, M. Ide, Thin Solid Films 371, 61 (2000).

[59] R.R. Goncalves, G. Carturan, L. Zampedri, M. Ferrari, M. Montagna, A. Chiasera, G.C. Righini, S. Pelli, S.J.L. Ribeiro, Y. Messaddeq, Appl. Phys. Lett. 81, 28 (2002).

[60] K. Suzuki, K. Kato, J. Am. Ceram. Soc. 92, S162 (2009).

[61] M. Villanueva-Ibanez, C. Le Luyer, O. Marty, J. Mugnier, Opt. Mater. 24, 51 (2003).

[62] S. Gopalan, S. Ramesh, S. Dutta, V.V. Garbhapu, IOP Conf. Series Mater. Sci. Eng. 310, 012125 (2018).

[63] S. Sayan, S. Aravamudhan, B.W. Busch, W.H Schulte, F. Cosandey, G.D. Wilk, T. Gustafsson, E. Garfunkel, J. Vac. Sci. Technol. A 20, 507 (2002).

[64] J.C. Hackley, T. Gougousi, Thin Solid Films 517, 6576 (2009)

[65] H. Wang, Y. Wang, J. Feng, C. Ye, B.Y. Wang, H.B. Wang, Q. Li, Y. Jiang, A.P. Huang, Z.S. Xiao, Appl. Phys. A 93, 681 (2008).

[66] Z. Ying, J. Sun, Z. Hu, W. Yu, N. Xu, J. Wu, J. Vac. Sci. Technol. A 30, 011506 (2012).

[67] Q. Li, S.J. Wang, W.D. Wang, D.Z. Chi, A.C.H. Huan, C.K. Ong, J. Electroceram. 16, 517 (2006).

[68] K. Yamamoto, S. Hayashi, M. Niwa, M. Asai, S. Horii, H. Miya, Appl. Phys. Lett. 83, 2229 (2003).

[69] M. Ramzan, M.F. Wasiq, A.M. Rana, S. Ali, M.Y. Nadeem, Appl. Surf. Sci. 283, 617 (2013).

[70] K. Cherkaoui, S. Monaghan, M.A. Negara, M. Modreanu, P.K. Hurley, D. O'Connell, S. McDonnell, G. Hughes, S. Wright, R.C. Barklie, P. Bailey, T.C.Q. Noakes, J. Appl. Phys. 104, 064113 (2008).

[71] Z.J. Yan, R. Xu, Y.Y. Wang, S. Chen, Y.L. Fan, Z.M. Jiang, Appl. Phys. Lett. 85, 85 (2004).

[72] M. Nath, A. Roy, Physica B 482, 43 (2016).

[73] C.C. Leu, S.T. Chen, F.K. Liu, Thin Solid Films 519, 5629 (2011)

[74] J.H. Choi, Y. Mao, J.P. Chang, Mater. Sci. Eng. R 72, 97 (2011)

[75] A. Jilani, M.S. Abdel-wahab, A.H. Hammad, in: Modern Technologies for Creating the Thin-Film Systems and Coatings, Ed. N. Nikitenkov, InTech, 2017.

[76] S.V. Aurobind, K.P. Amirthalingam, H. Gomathi, Adv. Coll. Interfac. 121, 1 (2006).

[77] J. Kang, D.Y. Kim, K.J. Chang, AIP Conf. Proc. 893, 263 (2007).

[78] Z. Yuanyang, W. Jiayu, X. Jianbin, Y. Fei, L. Qi, D. Yuehua, J. Semicond. 35, 042002 (2014).

[79] G. He, Q. Fang, G.H. Li, J.P. Zhang, L.D. Zhang, Appl. Surf. Sci. 253, 8483 (2007).

[80] M. Liu, L.D. Zhang, Q. Fang, J.P. Zhang, X.J. Wang, G. He, J. Phys. D 42, 195304 (2009).

[81] Y.S. Lim, Y.J. Im, S.S. Ha, C.H. Park, M.H. Jang, S.I. Choi, J.I. Park, M. Yi, J. Soc. Informat. Display 23, 384 (2015).

[82] D. Hai-Kuan, S. Li-Bin, Chin. Phys. Lett. 33, 016101 (2016). 
[83] Q. Li, K.M. Koo, W.M. Lau, P.F. Lee, J.Y. Dai, Z.F. Hou, X.G. Gong, Appl. Phys. Lett. 88, 182903 (2006).

[84] B. Lu, H. Lv, Yuming Zhang, Yimen Zhang, C. Liu, Superlatt. Microstruct. 99, 54 (2016).

[85] M. Mazur, D. Kaczmarek, J. Domaradzki, D. Wojcieszak, A. Poniedzialek, Coatings 6, 13 (2016).

[86] C. Ye, Y. Wang, Jun Zhang, Jieqiong Zhang, H. Wang, Y. Jiang, Appl. Phys. Lett. 99, 182904 (2011).

[87] T. Yu, C. Jin, X. Yang, Y. Dong, H. Zhang, L. Zhuge, X. Wu, Z. Wu, Appl. Surf. Sci. 258, 2953 (2012).

[88] M.H. Zhang, S.J. Rhee, C.Y. Kang, C.H. Choi, M.S. Akbar, S.A. Krishnan, T. Lee, I.J. Ok, F. Zhu, H.S. Kim, J.C. Lee, Appl. Phys. Lett. 87, 232901 (2005). 